\title{
CORRECTION
}

\section{Correction to: Toward an ecological aesthetic}

\section{Frederick Steiner ${ }^{1}$}

Published online: 8 April 2019

(c) Springer Nature Singapore Pte Ltd. 2019

\section{Correction to: Socio-Ecological Practice Research (2019) https://doi.org/10.1007/s42532-018-00004-0}

The article Toward an ecological aesthetic, written by Frederick Steiner, was originally published electronically on the publisher's internet portal (currently SpringerLink) on 2 January 2019 with open access.

With the author(s)' decision to step back from Open Choice, the copyright of the article changed on 8 April 2019 to ( ) Springer Nature Singapore Pte Ltd. 2018 and the article is forthwith distributed under the terms of copyright.

The original article can be found online at https://doi.org/10.1007/ s42532-018-00004-0.

Frederick Steiner

fsteiner@ design.upenn.edu

1 University of Pennsylvania School of Design, 102 Meyerson Hall, 210 South 34th Street, Philadelphia, PA 19104, USA 